\title{
Methane Content Estimation in DuongHuy Coal Mine
}

\author{
Van Thinh Nguyen ${ }^{1, *}$, Waldemar Mijał ${ }^{2}$, Vu Chi Dang ${ }^{1}$, and Thi Tuyet Mai Nguyen ${ }^{1}$ \\ ${ }^{1}$ Hanoi University of Mining and Geology, Faculty of Mining, Vietnam \\ ${ }^{2}$ AGH University Science and Technology, Faculty of Mining and Geoengineering, \\ A. Mickiewicza Av. 30, 30-059 Krakow, Poland
}

\begin{abstract}
Methane hazard has always been considered for underground coal mining as it can lead to methane explosion. In Quang Ninh province, several coal mines such as Mạo Khe coal mine, Khe Cham coal mine, especially Duong Huy mine that have high methane content. Experimental data to examine contents of methane bearing coal seams at different depths are not similar in Duong coal mine. In order to ensure safety, this report has been undertaken to determine a pattern of changing methane contents of coal seams at different exploitation depths in Duong Huy underground coal mine.

Key words - coal mining, methane hazard, prediction.
\end{abstract}

\section{Introduction to DuongHuy coal mine [1, 3]}

DuongHuy coal mine located in Duong Huy commune, Cam Pha city, Quang Ninh province. Duong Huy coal mine has an area $3,6 \mathrm{~km}^{2}$, within the limits of the coordinates (HN72 coordinate system, Vietnam):

$\mathrm{X}$ : From 27.600 to 30.000

Y: From 421.500 to 423.000

- The North, it borders on Mine Construction Company

- The East, it borders with KheCham coal mine

- The South, it borders on 86 coal Company

- The West, it borders with Khe Tam coal mine

The expected output of Duong Huy coal mine in 2017 is 1,400,000 tons/year.

\section{Coal sampling and methane gas analysis sequence [2]}

At the coal seams of Duong Huy coal mine, drill holes into the coal seams. When drilling to a depth of $2.5 \mathrm{~m}$, stop drilling. Take samples of coal from the whitewalls at the bottom of the borehole, with each bore taking two samples. The first specimen was taken at a long of 2.5 , with the second sample taken at a long of $4.5 \mathrm{~m}$. Choice of particle size from 1 to $2 \mathrm{~mm}$. Samples of coal are fed to the vibrating mill for grinding, the coal sample is crushed by the marbles in the cylinders as they move up and down. Maximum grinding time is 5 hours.

* Corresponding author: nguyenthinhtkv@gmail.com 
After grinding, the gas is separated from the coal sample by the MOD-1 gas separator. All the gas in the coal sample jug is separated and transferred to the sample bag. Gas separation parameters are used to calculate exactly the volume of gas to be extracted.

The specimen after being separated by MOD-1 was introduced into an analytical gas analyzer (Fig. 1) to determine the volume of methane contained in the sample. The extracted gas composition was analyzed by VARIAN gas chromatography. Analysis results from the VARIAN machine will determine the volume of methane gas from each sample of coal (Analysis results are presented in Section 3).

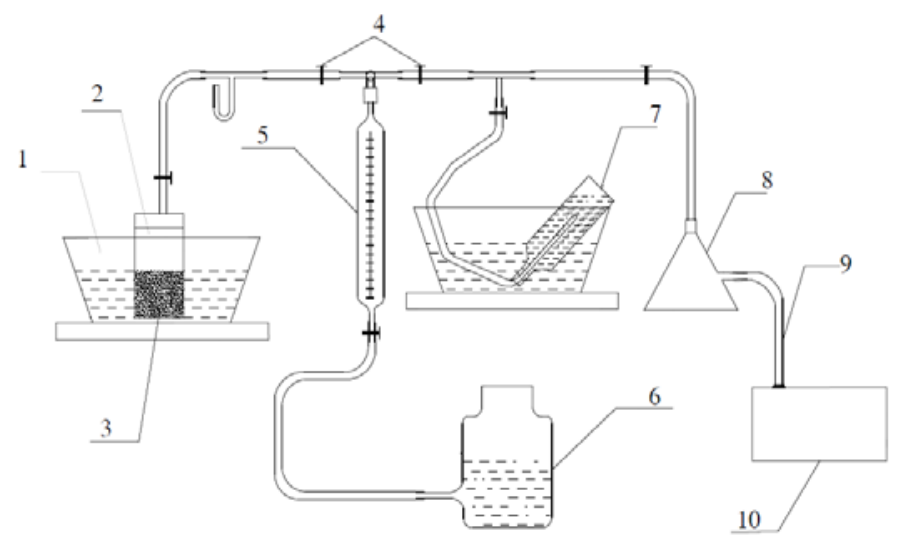

Fig. 1. Gas separation diagram by vacuum heat: 1 - Hot water bottle; 2 - Coal sample container; 3 Electric stove; 4 - Regulating valve; 5 - Piet measured the volume; 6 - Pressure vessel; 7 - Bottle containing specimen separation gas; 8 - Intermediate gas cylinders; 9 - Tube; 10 - Vacuum machine

From the results of the analysis, establish a relationship between the trend of methane density and the depth of the coal seam by using Excel software to construct methane gas prediction graph (the least squares method). Results of methane content forecast are presented in Section 4.

\section{Reasults of analysis of methane content in Duong Huy coal mine}

The results of the analysis are shown in Table 1 to Table 4 with the corresponding coal seams.

Table 1. Analysis results $\mathrm{CH}_{4}$ at No. 6, No. 7 and No. 8 coal seam

\begin{tabular}{|c|c|c|c|c|c|c|c|c|}
\hline \multicolumn{3}{|c|}{ No. 6 coal seam } & \multicolumn{3}{c|}{ No. 7 coal seam } & \multicolumn{3}{c|}{ No. 8 coal seam } \\
\hline STT & Depths & $\begin{array}{c}\mathbf{C H}_{\mathbf{4}} \\
\text { content, } \\
\mathbf{m}^{\mathbf{3}} / \mathbf{T K C}\end{array}$ & $\mathbf{S T T}$ & Depths & $\begin{array}{c}\mathbf{C H}_{\mathbf{4}} \\
\text { content, } \\
\mathbf{m}^{\mathbf{3}} / \mathbf{T K C}\end{array}$ & $\mathbf{S T T}$ & Depths & $\begin{array}{c}\mathbf{C H}_{4} \\
\text { content, } \\
\mathbf{m}^{3} / \mathbf{T K C}\end{array}$ \\
\hline 1 & +50 & 0.271 & 1 & +38 & 0.37784 & 1 & +100 & 0.1406 \\
\hline 2 & +38 & 1.4 & 2 & 0 & 0.436 & 2 & +70 & 0.119 \\
\hline 3 & 0 & 1.90045 & 3 & -35 & 0.56338 & 3 & +38 & 0.1392 \\
\hline 4 & -35 & 1.9229 & 4 & -35 & 0.5782 & 4 & 0 & 0.28566 \\
\hline 5 & -80 & 2.57567 & 5 & -100 & 0.61374 & 5 & -40 & 0.74581 \\
\hline 6 & -100 & 2.82104 & & & & & & \\
\hline
\end{tabular}


Table 2. Analysis results $\mathrm{CH}_{4}$ at No. 9, No. 10 and No. 11 coal seam

\begin{tabular}{|c|c|c|c|c|c|c|c|c|}
\hline \multicolumn{3}{|c|}{ No.9 coal seam } & \multicolumn{3}{c|}{ No. 10 coal seam } & \multicolumn{3}{|c|}{ No. 11 coal seam } \\
\hline STT & Depths & $\begin{array}{c}\mathbf{C H}_{\mathbf{4}} \\
\text { content, } \\
\mathbf{m}^{3} / \mathbf{T K C}\end{array}$ & STT & Depths & $\begin{array}{c}\mathbf{C H}_{\mathbf{4}} \\
\text { content, } \\
\mathbf{m}^{\mathbf{3}} / \mathbf{T K C}\end{array}$ & STT & Depths & $\begin{array}{c}\mathbf{C H}_{\mathbf{4}} \\
\text { content, } \\
\mathbf{m}^{\mathbf{3}} / \mathbf{T K C}\end{array}$ \\
\hline 1 & +90 & 0.3657 & 1 & +38 & 0.23 & 1 & +38 & 0.009 \\
\hline 2 & +55 & 0.45 & 2 & 0 & 0.2946 & 2 & 0 & 0.6808 \\
\hline 3 & +38 & 0.57 & 3 & -50 & 1.39559 & 3 & -100 & 1.80868 \\
\hline 4 & 0 & 0.5465 & 4 & -100 & 2.02255 & & & \\
\hline 5 & -20 & 0.68 & & & & & & \\
\hline 6 & -100 & 1.60856 & & & & & & \\
\hline
\end{tabular}

Table 3. Analysis results $\mathrm{CH}_{4}$ at No. 12, No. 13 and No. 14 coal seam

\begin{tabular}{|c|c|c|c|c|c|c|c|c|}
\hline \multicolumn{2}{|c|}{ No. 12 coal seam } & \multicolumn{3}{c|}{ No. 13 coal seam } & \multicolumn{3}{|c|}{ No. 14 coal seam } \\
\hline STT & Depths & $\begin{array}{c}\mathbf{C H}_{4} \\
\text { content, } \\
\mathbf{m}^{3} / \text { TKC }\end{array}$ & STT & Depths & $\begin{array}{c}\mathbf{C H}_{\mathbf{4}} \\
\text { content, } \\
\mathbf{m}^{3} / \mathbf{T K C}\end{array}$ & STT & Depths & $\begin{array}{c}\mathbf{C H}_{4} \\
\text { content, } \\
\mathbf{m}^{3} / \text { TKC }\end{array}$ \\
\hline 1 & +70 & 0.179 & 1 & +100 & 0.02 & 1 & +20 & 1.048 \\
\hline 2 & +38 & 0.1884 & 2 & +50 & 0.1819 & 2 & +10 & 1.02347 \\
\hline 3 & 0 & 0.13665 & 3 & +38 & 0.2447 & 3 & -20 & 2.02751 \\
\hline 4 & -30 & 0.2477 & 4 & +25 & 0.23558 & 4 & -100 & 3.407 \\
\hline 5 & -70 & 0.281 & 5 & 0 & 0.281 & & & \\
\hline 6 & -100 & 0.38801 & 6 & -50 & 0.31125 & & & \\
\hline & & & 7 & -100 & 0.33033 & & & \\
\hline
\end{tabular}

Table 4. Analysis results $\mathrm{CH}_{4}$ at No. $7 \mathrm{KN}$, No. $9 \mathrm{KN}$ and No. $12 \mathrm{DB}$ coal seam

\begin{tabular}{|c|c|c|c|c|c|c|c|c|}
\hline \multicolumn{3}{|c|}{ No. 7KN coal seam } & \multicolumn{3}{c|}{ No. 9KN coal seam } & \multicolumn{3}{c|}{ No. 12DB coal seam } \\
\hline STT & Depths & $\begin{array}{c}\mathbf{C H}_{\mathbf{4}} \\
\text { content, } \\
\mathbf{m}^{\mathbf{3}} / \text { TKC }\end{array}$ & STT & Depths & $\begin{array}{c}\mathbf{C H}_{\mathbf{4}} \\
\text { content, } \\
\mathbf{m}^{\mathbf{3}} / \mathbf{T K C}\end{array}$ & STT & Depths & $\begin{array}{c}\mathbf{C H}_{\mathbf{4}} \\
\text { content, } \\
\mathbf{m}^{\mathbf{3}} / \mathbf{T K C}\end{array}$ \\
\hline 1 & +100 & 2.609 & 1 & +80 & 0.08259 & 1 & +100 & 0.16082 \\
\hline 2 & +70 & 3.747 & 2 & +55 & 0.00538 & 2 & +70 & 0.17933 \\
\hline 3 & +60 & 3.908 & 3 & +38 & 0.00653 & 3 & +65 & 0.37121 \\
\hline 4 & +38 & 4.29614 & & & & 4 & +38 & 0.88438 \\
\hline 5 & 0 & 4.23136 & & & & & & \\
\hline 6 & -15 & 4.32103 & & & & & & \\
\hline 7 & -35 & 4.861 & & & & & & \\
\hline
\end{tabular}

\section{Results of methane content forecast}

From the methane content figures in Tables 1 to Tables 4. We use Excel software to graph the gas variability at different levels of coal seams.

The results of the analysis are shown in table 5 to table 8, and Figure 2 to Figure 13 with the corresponding coal seams. 


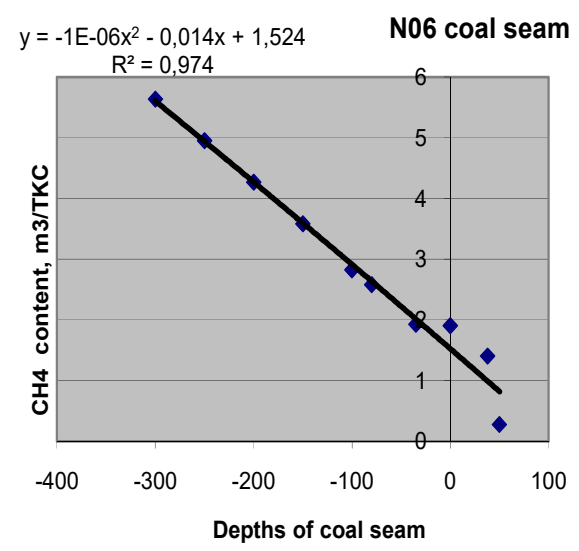

Fig. 2. Distribution chart $\mathrm{CH}_{4}$ at No. 6 coal seam

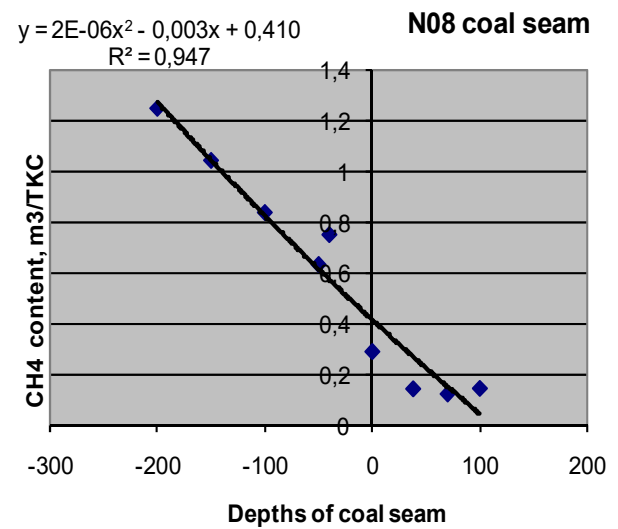

Fig. 4. Distribution chart $\mathrm{CH}_{4}$ at No. 8 coal seam

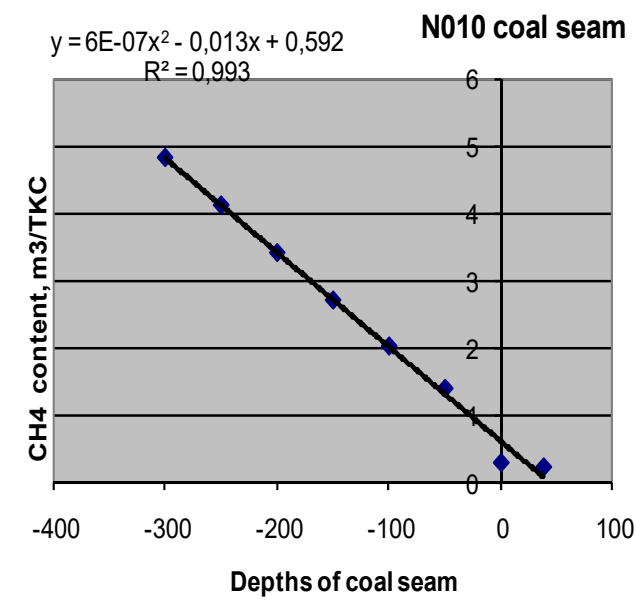

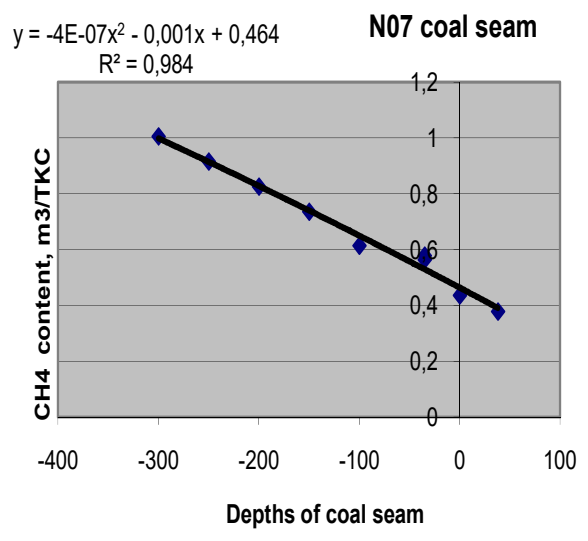

Fig. 3. Distribution chart $\mathrm{CH}_{4}$ at No. 7 coal seam

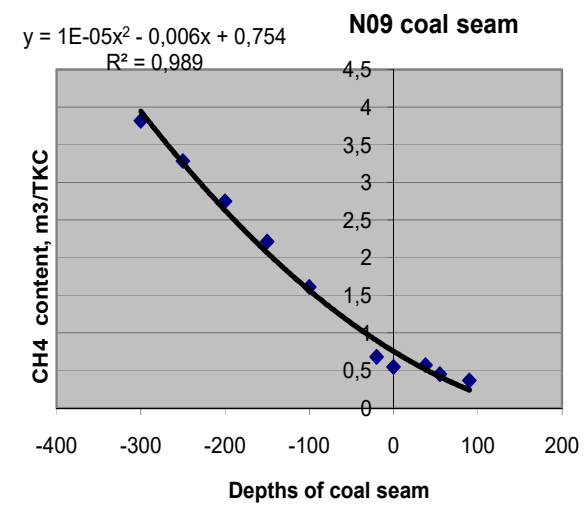

Fig. 5. Distribution chart $\mathrm{CH}_{4}$ at No. 9 coal seam

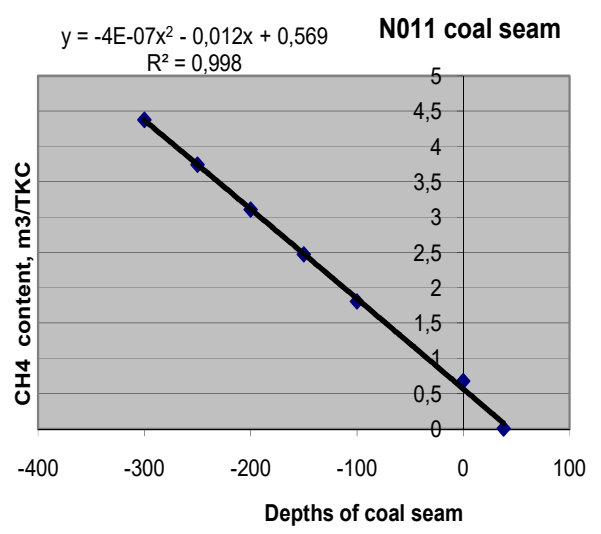

Fig. 6. Distribution chart $\mathrm{CH}_{4}$ at No. 10 coal seam Fig. 7. Distribution chart $\mathrm{CH}_{4}$ at No. 11 coal seam 

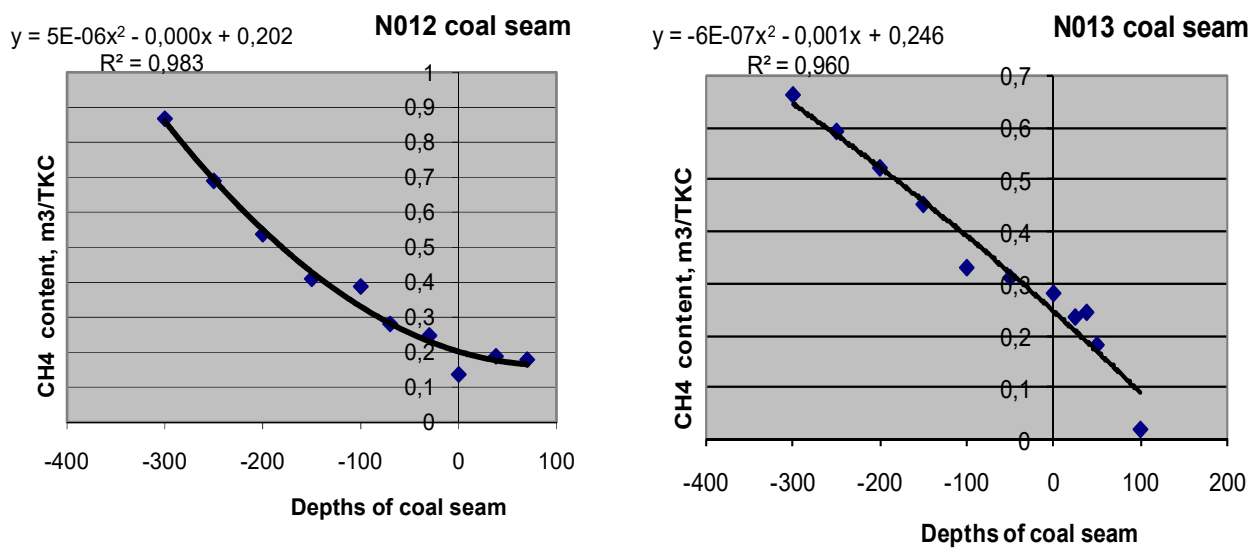

Fig .8. Distribution chart $\mathrm{CH}_{4}$ at No. 12 coal seam Fig. 9. Distribution chart $\mathrm{CH}_{4}$ at No. 13 coal seam

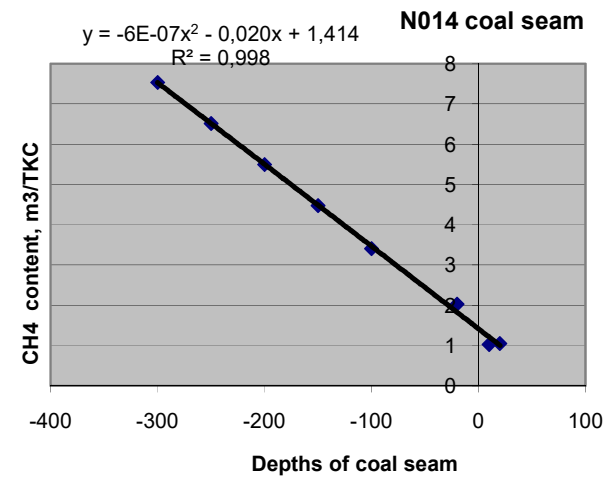

Fig. 10. Distribution chart $\mathrm{CH}_{4}$ at No. 14 coal seam

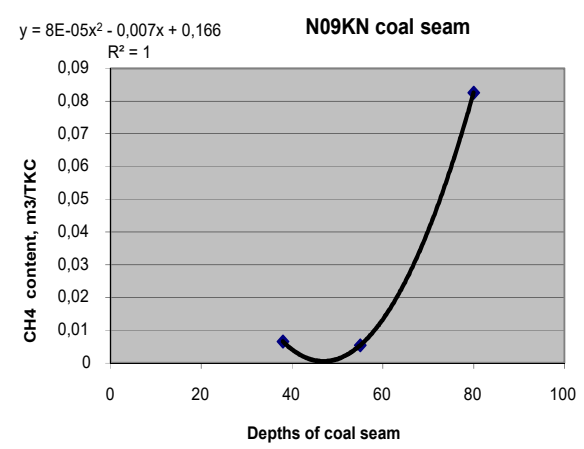

Fig. 12. Distribution chart $\mathrm{CH}_{4}$ at No. $9 \mathrm{KN}$ coal seam

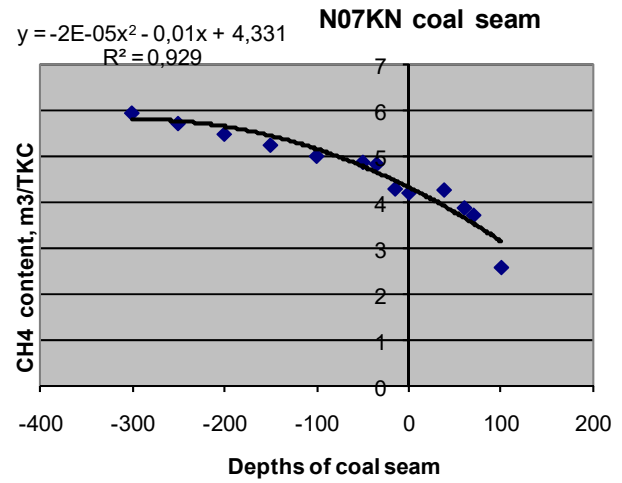

Fig. 11. Distribution chart $\mathrm{CH}_{4}$ at No. $7 \mathrm{KN}$ coal seam

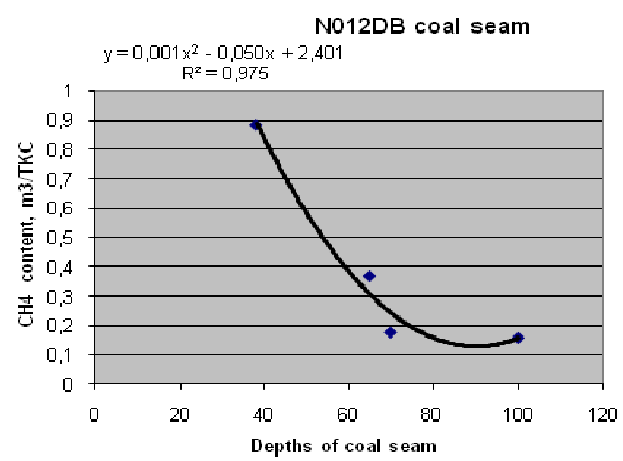

Fig. 13. Distribution chart $\mathrm{CH}_{4}$ at No. $12 \mathrm{DB}$ coal seam 
Table 5. Forecast results $\mathrm{CH}_{4}$ at No. 6, No. 7 and No. 8 coal seam

\begin{tabular}{|c|c|c|c|c|c|c|c|c|}
\hline \multicolumn{2}{|c|}{ No. 6 coal seam } & \multicolumn{3}{c|}{ No. 7 coal seam } & \multicolumn{3}{c|}{ No. 8 coal seam } \\
\hline STT & Depths & $\begin{array}{c}\mathbf{C H}_{\mathbf{4}} \\
\text { content, } \\
\mathbf{m}^{\mathbf{3}} / \mathbf{T K C}\end{array}$ & STT & Depths & $\begin{array}{c}\mathbf{C H}_{\mathbf{4}} \\
\text { content, } \\
\mathbf{m}^{\mathbf{3}} / \mathbf{T K C}\end{array}$ & STT & Depths & $\begin{array}{c}\mathbf{C H}_{\mathbf{4}} \\
\text { content, } \\
\mathbf{m}^{\mathbf{3}} / \mathbf{T K C}\end{array}$ \\
\hline 1 & -150 & 3.5807 & 1 & -150 & 0.7353 & 1 & -50 & 0.6282 \\
\hline 2 & -200 & 4.2657 & 2 & -200 & 0.8253 & 2 & -100 & 0.8332 \\
\hline 3 & -250 & 4.9507 & 3 & -250 & 0.9153 & 3 & -150 & 1.0382 \\
\hline 4 & -300 & 5.6357 & 4 & -300 & 1.0053 & 4 & -200 & 1.2432 \\
\hline & & & & & & 5 & -250 & 1.4482 \\
\hline & & & & & & 6 & -300 & 1.6532 \\
\hline
\end{tabular}

Table 6. Forecast results $\mathrm{CH}_{4}$ at No. 9 , No. 10 and No. 11 coal seam

\begin{tabular}{|c|c|c|c|c|c|c|c|c|}
\hline \multicolumn{3}{|c|}{ No. 9 coal seam } & \multicolumn{3}{c|}{ No. 10 coal seam } & \multicolumn{3}{c|}{ No. 11 coal seam } \\
\hline STT & Depths & $\begin{array}{c}\mathbf{C H}_{\mathbf{4}} \\
\text { content, } \\
\mathbf{m}^{\mathbf{3}} / \mathbf{T K C}\end{array}$ & STT & Depths & $\begin{array}{c}\mathbf{C H}_{\mathbf{4}} \\
\text { content, } \\
\mathbf{m}^{\mathbf{3}} / \mathbf{T K C}\end{array}$ & STT & Depths & $\begin{array}{c}\mathbf{C H}_{\mathbf{4}} \\
\text { content, } \\
\mathbf{m}^{\mathbf{3}} / \mathbf{T K C}\end{array}$ \\
\hline 1 & -150 & 2.2119 & 1 & -150 & 2.7046 & 1 & -150 & 2.4757 \\
\hline 2 & -200 & 2.7469 & 2 & -200 & 3.4096 & 2 & -200 & 3.1107 \\
\hline 3 & -250 & 3.2819 & 3 & -250 & 4.1146 & 3 & -250 & 3.7457 \\
\hline 4 & -300 & 3.8169 & 4 & -300 & 4.8196 & 4 & -300 & 4.3807 \\
\hline
\end{tabular}

Table 7. Forecast results $\mathrm{CH}_{4}$ at No. 12 , No. 13 and No. 14 coal seam

\begin{tabular}{|c|c|c|c|c|c|c|c|c|}
\hline \multicolumn{2}{|c|}{ No. 12 coal seam } & \multicolumn{3}{c|}{ No. 13 coal seam } & \multicolumn{3}{c|}{ No. 14 coal seam } \\
\hline STT & Depths & $\begin{array}{c}\mathbf{C H}_{\mathbf{4}} \\
\text { content, } \\
\mathbf{m}^{\mathbf{3}} / \mathbf{T K C}\end{array}$ & STT & Depths & $\begin{array}{c}\mathbf{C H}_{\mathbf{4}} \\
\text { content, } \\
\mathbf{m}^{\mathbf{3}} / \mathbf{T K C}\end{array}$ & STT & Depths & $\begin{array}{c}\mathbf{C H}_{\mathbf{4}} \\
\text { content, } \\
\mathbf{m}^{\mathbf{3}} / \mathbf{T K C}\end{array}$ \\
\hline 1 & -150 & 0.4099 & 1 & -150 & 0.4517 & 1 & -150 & 4.4772 \\
\hline 2 & -200 & 0.5374 & 2 & -200 & 0.5217 & 2 & -200 & 5.4972 \\
\hline 3 & -250 & 0.6899 & 3 & -250 & 0.5917 & 3 & -250 & 6.5172 \\
\hline 4 & -300 & 0.8674 & 4 & -300 & 0.6617 & 4 & -300 & 7.5372 \\
\hline
\end{tabular}

Table 8. Forecast results $\mathrm{CH}_{4}$ at No. $7 \mathrm{KN}$, No. $9 \mathrm{KN}$ and No. $12 \mathrm{DB}$ coal seam

\begin{tabular}{|c|c|c|c|c|c|c|c|c|}
\hline \multicolumn{3}{|c|}{ No. 7KN coal seam } & \multicolumn{3}{c|}{ No. 9KN coal seam } & \multicolumn{3}{|c|}{ No. 12DB coal seam } \\
\hline STT & Depths & $\begin{array}{c}\text { CH4 } \\
\text { content, } \\
\mathbf{m}^{3} / \text { TKC }\end{array}$ & STT & Depths & $\begin{array}{c}\text { CH4 } \\
\text { content, } \\
\mathbf{m}^{3} / \text { TKC }\end{array}$ & STT & Depths & $\begin{array}{c}\mathbf{C H}_{4} \\
\text { content, } \\
\mathbf{m}^{3} / \text { TKC }\end{array}$ \\
\hline 1 & -50 & 4.9 & 1 & 0 & 0,166 & 1 & 0 & 2,401 \\
\hline 2 & -100 & 5.031 & 2 & -20 & 0,33552 & 2 & -20 & 2,581 \\
\hline 3 & -150 & 5.2735 & 3 & -50 & 0,7005 & 3 & -50 & 3,151 \\
\hline 4 & -200 & 5.511 & 4 & -80 & 1,19832 & 4 & -80 & 4,081 \\
\hline 5 & -250 & 5.7435 & 5 & -100 & 1,604 & 5 & -100 & 4,901 \\
\hline 6 & -300 & 5.971 & 6 & -150 & 2,8765 & 6 & -150 & 7,651 \\
\hline
\end{tabular}




\section{Conclusions}

From the results of the analysis and forecast results from Table 1 to Tables 8 and Figures 2 to Figures 13 show the degree of methane storage in the coal seams of the mines with great variation. And the greater the depth, the higher the gas density. Specific for each seam as follows:

- For No. 6 coal seam: From depths level +38 to depths level -150 the density of methane contained in the coal seam is determined and predicted from $0.271 \mathrm{~m}^{3} / \mathrm{TKC}$ to 3.5807 $\mathrm{m}^{3} /$ TKC (This coal seam is ranked I according to QCVN / 03-BCT / 2011, Vietnam). From depths level -200 to depths level -300 , The density of methane contained in the coal seam is forecasted from $4.2657 \mathrm{~m}^{3} / \mathrm{TKC}$ to $5.6357 \mathrm{~m}^{3} / \mathrm{TKC}$ (This coal seam is ranked II according to QCVN / 03-BCT / 2011, Vietnam [4]).

- For No. 7 coal seam: From depths level +38 to depths level -300 the density of methane contained in the coal seam is determined and forecasted from $0.37784 \mathrm{~m}^{3} / \mathrm{TKC}$ to $1.0053 \mathrm{~m}^{3} / \mathrm{TKC}$ (This coal seam is ranked I according to QCVN / 03-BCT / 2011, Vietnam [4]).

- For No. 8 coal seam: From depths level +100 to depths level -300 the density of methane contained in the coal seam is determined and forecasted from $0.1406 \mathrm{~m}^{3} / \mathrm{TKC}$ to $1.6532 \mathrm{~m}^{3} /$ TKC (This coal seam is ranked I according to QCVN / 03-BCT / 2011, Vietnam [4]).

- For No. 9 coal seam: From depths level +90 to depths level -300 the density of methane contained in the coal seam is determined and forecasted from $0.3657 \mathrm{~m}^{3} / \mathrm{TKC}$ to 3.8169 $\mathrm{m}^{3} /$ TKC (This coal seam is ranked I according to QCVN / 03-BCT / 2011, Vietnam [4]).

- For No. 10 coal seam: From depths level +38 to depths level -200 the density of methane contained in the coal seam is determined and forecasted from $0.23 \mathrm{~m}^{3} / \mathrm{TKC}$ to $3.4096 \mathrm{~m}^{3} /$ TKC (This coal seam is ranked I according to QCVN / 03-BCT / 2011, Vietnam). From depths level -250 to depths -300 , the density of methane contained in the coal seam is forecasted from $4.1146 \mathrm{~m}^{3} / \mathrm{TKC}$ to $4.8196 \mathrm{~m}^{3} / \mathrm{TKC}$ (This coal seam is ranked II according to QCVN / 03-BCT / 2011, Vietnam [4]).

- For No. 11 coal seam: From depths level +38 to depths level -250 the density of methane contained in the coal seam is determined and forecasted from $0.009 \mathrm{~m}^{3} / \mathrm{TKC}$ to $3.7457 \mathrm{~m}^{3} /$ TKC (This coal seam is ranked I according to QCVN / 03-BCT / 2011, Vietnam). At depths below level -300 , the methane content forecast is greater than $4.3807 \mathrm{~m}^{3} /$ TKC (This coal seam is ranked II according to QCVN / 03-BCT / 2011, Vietnam [4]).

- For No. 12 coal seam: From depths level +70 to depths level -300 the density of methane contained in the coal seam is determined and forecasted from $0.179 \mathrm{~m}^{3} / \mathrm{TKC}$ to $0.8674 \mathrm{~m}^{3} / \mathrm{TKC}$ (This coal seam is ranked I according to QCVN / 03-BCT / 2011, Vietnam [4]).

- For No. 13 coal seam: From depths level +100 to depths level -300 the density of methane contained in the coal seam is determined and forecasted from $0.02 \mathrm{~m}^{3} / \mathrm{TKC}$ to $0.6617 \mathrm{~m}^{3} / \mathrm{TKC}$ (This coal seam is ranked I according to QCVN / 03-BCT / 2011, Vietnam [4]).

- For No. 14 coal seam: From depths level +20 to depths level -100 the density of methane contained in the coal seam is determined and forecasted from $1.048 \mathrm{~m}^{3} / \mathrm{TKC}$ to $3.407 \mathrm{~m}^{3} /$ TKC (This coal seam is ranked I according to QCVN / 03-BCT / 2011, Vietnam). From depths level -150 to depths -300 , the density of methane contained in the coal seam is forecasted from $4.4772 \mathrm{~m}^{3} /$ TKC to $7.5372 \mathrm{~m}^{3} / \mathrm{TKC}$ (This coal seam is ranked II according to QCVN / 03-BCT / 2011, Vietnam [4]).

- For No. 7KN coal seam: From depths level +100 to depths level +60 the density of methane contained in the coal seam is determined and forecasted from $2.609 \mathrm{~m}^{3} / \mathrm{TKC}$ to 
$3.908 \mathrm{~m}^{3} / \mathrm{TKC}$ (This coal seam is ranked I according to QCVN / 03-BCT / 2011, Vietnam). From depths level +38 to depths -300 , the density of methane contained in the coal seam is forecasted from $4.29614 \mathrm{~m}^{3} /$ TKC to $5.971 \mathrm{~m}^{3} / \mathrm{TKC}$ (This coal seam is ranked II according to QCVN / 03-BCT / 2011, Vietnam [4]).

- For No. 9KN coal seam: From depths level +80 to depths level -150 the density of methane contained in the coal seam is determined and forecasted from $0.08259 \mathrm{~m}^{3} / \mathrm{TKC}$ to $2,8765 \mathrm{~m}^{3} / \mathrm{TKC}$ (This coal seam is ranked I according to QCVN / 03-BCT / 2011, Vietnam [4]).

- For No. 12DB coal seam: From depths level +100 to depths level -50 the density of methane contained in the coal seam is determined and forecasted from $0.16082 \mathrm{~m}^{3} / \mathrm{TKC}$ to $3,151 \mathrm{~m}^{3} /$ TKC (This coal seam is ranked I according to QCVN / 03-BCT / 2011, Vietnam). From depths level -80 to depths -150 , the density of methane contained in the coal seam is forecasted from $4,081 \mathrm{~m}^{3} /$ TKC to $7,651 \mathrm{~m}^{3} / \mathrm{TKC}$ (This coal seam is ranked II according to QCVN / 03-BCT / 2011, Vietnam [4]).

Sample analysis results show that all coal seams of Duong Huy Coal Mine currently ranked I according to QCVN / 03-BCT / 2011, Vietnam

However, the results at the deeper levels of the coal seams show that in the seams No. 6, No. 10 , No. 11 , No. 14 , No. 7 KN, No. 12DB will rank II. Particularly coal seams No. 14 and No. 12DB have methane content reaching the threshold of rank II close to rank III (methane content of $\geq 8 \mathrm{~m}^{3} / \mathrm{TKC}$ )

\section{References}

1. Mining curent status of Duong Huy coal mine in 2017. Technical Department, Duong Huy coal Company, Quangninh-Vietnam (2017)

2. Report on sampling results, annual methane analysis for 2016. Mine safety centerVinacomin, Quangninh, Vietnam (2016)

3. Report on geological exploration results of Duong Huy coal mine, 2013. Mining geology company -TKV, Quangninh,Vietnam (2013)

4. Vietnam National Technical Regulation on safety in underground coal mining QCVN01:2011/BCT. Ministry of Industry and Trade, Hanoi, Vietnam (2011) 